\title{
PENGARUH INSENTIF, KOMPENSASI DAN REWARD TERHADAP KINERJA KARYAWAN PT. BRI (PERSERO).TBK KANTOR CABANG BENGKULU
}

\author{
Fauzan \\ Program Studi Manajemen \\ Fakultas Ekonomi Universitas PROF. DR. Hazairin, SH Bengkulu
}

\begin{abstract}
This study aims to determine how much influence the incentives, compensation and rewards on the performance of employees of PT. BRI Persero Tbk Bengkulu Branch Office. Data analysis method uses Multiple Linear Regression, with Incentives as Free Variable (X1), Compensation as Free Variable (X2), Reward as Free Variable (X3) and Employee Performance as dependent variable (Y). that there is a positive influence between the four variables. The value of the correlation coefficient (r) is 0.760 and the coefficient of determination Adjusted $\mathrm{R}$ square of 0.549 shows the influence of incentives, compensation, and rewards on Employee Performance is very strong.
\end{abstract}

Keywords: Incentives, Compensation and Rewards

\section{PENDAHULUAN}

Pentingnya perkembangan Manajemen Sumber Daya Manusia sekarang ini didorong dengan kemajuan zaman, pendidikan, ilmu pengetahuan, teknologi, serta tuntutan daya saing produksi barang dan jasa yang dihasilkan. Perkembangan ini dimulai sejak adanya kerjasama dan pembagian kerja diantara dua orang atau lebih. Pengelolaan Sumber Daya ini sangat penting untuk mencapai tujuan organisasi melalui manajemen yang merupakan alat untuk mencapai tujuan tersebut. Manajemen yang baik akan memudahkan terwujudnya tujuan perusahaan, karyawan dan masyarakat. Dengan manajemen daya guna dan hasil guna unsur-unsur manajemen akan dapat di tingkatkan. Dalam pencapaian tujuan perusahaan, serta peningkatan kinerja karyawan juga perlu memperhatikan unsure-unsur yang menjadi hal penting dalam pemenuhannya, diantaranya adalah pemberian insentif kepada setiap karyawannya disebuah perusahaan. insentif ini dapat digunakan sebagai alat untuk memotivasi karyawan dalam rangka untuk meningkatkan kinerja mereka dan merangsang para karyawan untuk berperan aktif dalam proses menuju kesuksesan perusahaan. Selain itu, upah merupakan salah satu faktor yang mempengaruhi kinerja karyawan.

Menurut Heidjrachman dan Husnan ( dalam gecko dkk : 2009 ) mengatakan bahwa pengupahan insentif dimaksudkan untuk memberikan upah atau gaji yang berbeda. Jadi dua orang karyawan yang mempunyai jabatan yang sama bisa menerima upah yang berbeda dikarenakan prestasi kerja yang berbeda. Dari pengertian tersebut Insentif merupakan suatu imbalan yang telah diberikan dan diterima oleh seseorang di dalam hubungan kerja yang berupa uang, melalui perjanjian kerja, Insentif sebenarnya merupakan imbalan atas prestasi karyawan, semakin tinggi prestasi karyawan 
seharusnya semakin besar pula insentif yang akan diterima. Prestasi ini biasanya dinyatakan sebagai kinerja maupun produktivitas.

Tidak hanya itu pemberian imbalan yang layak adalah kebijaksanaan kompensasi berlandaskan Pancasila dan Undang-Undang Dasar 1945 yang diatur dalam hubungan industri Pancasila serta bebagai peraturan lainya. Menurut Mukaram dan Mawarsyah, mendefinisikan Kompensasi adalah penghargaan/imbalan-langsung maupun tidak langsung, finansial maupun non-finansial yang adil dan layak kepada karyawan, sebagai balasan atas kontribusi mereka terhadap pencapaian tujuan organisasi. ( Blog Shinu Bagus : 2011) Kompensasi harus dapat meningkatkan kesejahteraan dan menambah produktivitas kerja sebagai kewajiban bagi setiap karyawan. Bahkan sekarang apabila seorang karyawan bekerja dengan dinilai dari hasil pertimbangan dan berdasarkan loyalitas terhadap perusahaan maka layak diberikan semacam hadiah atau reward, dimana pengertian dari reward itu sendiri adalah suatu yang berfungsi sebagai alat penghargaan, yang penting bagi karyawan yang dapat memperbesar kemungkinan bertambah giatnya usaha untuk mempertinggi memperbaiki prestasi, serta mempengaruhi karyawan lain. (Santri MS : 2010), Maka pemberian reward sangat penting untuk meningkatkan motivasi kegiatan yang produktif pada perusahaan. Kinerja sendiri merupakan hasil kerja yang dicapai oleh individu yang disesuaikan dengan peran dalam hal dunia kerja. PT. Bank Rakyat Indonesia (Persero). Tbk Kantor Cabang Bengkulu yang memiliki karyawan yang ahli di bidangnya masing - masing yang semuanya harus memberikan peningkatan kinerja. Agar karyawan dapat bekerja secara efektif dan efisien,harus didukung oleh faktor pemberian insentif, kompensasi dan reward agar kinerja dan prestasi terus dicapai dan termotivasi untuk jauh lebih baik lagi bagi seluruh karyawan yang ada di PT. Bank Rakyat Indonesia Kantor Cabang Bengkulu.

\section{TINJAUAN PUSTAKA}

\section{Manajemen Sumber Daya Manusia}

Pada saat sekarang ini istilah Manajemen Sumber Daya Manusia sudah banyak dikenal di negara kita Indonesia. Manajemen yang berasal dari kata "to manage" yang artinya mengatur. Manajemen dan organisasi bukan tujuan, tetapi hanya alat untuk mencapai tujuan yang diinginkan, karena tujuan yang ingin dicapai itu adalah pelayanan dan laba (profit). Walapun manajemen dan organisasi hanya merupakan " alat dan wadah" saja tetapi harus diatur dengan sebaik - baiknya. Karena jika manajemen dan organisasi ini baik maka secara optimal dapat diwujudkan, dengan adanya bantuan dari beberapa sumber daya manusia yang menjalankan semua fungsi dari manajemen itu sendiri serta didukung dengan perkembangan teknologi sehingga sumber daya manusia dapat bekerja secara efektif dan efisien sesuai tujuan organisasi. pemborosan terhindari, dan semua potensi yang dimiliki akan lebih bermanfaat.

Ada banyak sumber literatur yang memberikan pengertian tentang manajemen sumber daya manusia antara lain :

1. Edwin B. Flippo ( 1989 : 5 ). Manajemen Sumber Daya Manusia ( manajemen personalia ) adalah : perencanaan, pengorganisasian, pengarahan, dan pengendalian atas pengadaan tenaga kerja, pengembangan kompensasi, integrasi, pemeliharaan, 


\section{CREATIVE RESEARCH MANAGEMENT JOURNAL-CRMJ Juli}

2018

dan pemisahaan sumber daya manusia dengan tujuan mencapai tujuan perseorangan, organisasi, dan masyarakat.

2. Soekidjo Notoatmodjo ( 2003 : 3 ). Manajemen sumber daya manusia adalah terlihat dari dua aspek yang sangat penting, yakni kuantitas dan kualitas. Kuantitas menyangkut jumlah sumber daya manusia ( penduduk ) yang kurang penting kontribusinya dalam pembangunan, dibandingkan dengan aspek kualitas. Bahkan kualitas sumber daya manusia tanpa di sertai dengan kualitas yang baik akan menjadi beban pembangunan suatu bangsa, kualitas tersebut menyangkut kemampuan, baik kemampuan fisik maupun kemampuan nonfisik (kecerdasan dan mental).

Pengertian manajemen sumber daya manusia menurut A.A Anwar Prabu Mangkunegara adalah sebagai berikut :

"Manajemen sumber daya manusia merupakan suatu perencanaan, pengorganisasian, pengkoordinasian, pelaksanaan, dan pengawasan terhadap pengadaan, pemberian balas jasa, pengintegrasian, pemeliharaan, pemisahan tenaga kerja dalam rangka mencapai tujuan organisasi." ( Iis Yasiroh 2010:10)

Fungsi - fungsi MSDM terdiri dari perencanaan, pengorganisasian, pengarahan, pengendalian, pengadaan, pengembangan kompensasi, penghargaan (reward), pengintegritas, pemelirharaan, kedisplinan, dan pemberhentian. Tujuannya adalah agar perusahaan mendapatkan rentabilitas laba yang lebih besar dari persentase tingkat suku bunga Bank. Karyawan bertujuan mendapatkan kepuasan dari pekerjaannya. Dari itulah mengapa perusahaan memberikan dan terus melakukan pengembangan kompensasi, insentif serta sebuah penghargaan/reward terhadap karyawan yang mampu memberikan loyalitas dan peningkatan kinerja.

\section{Insentif}

Menurut Nitisemito (dalam Selly lovita 2010 : 10 ) insentif adalah penghasilan tambahan yang akan diberikan kepada para karyawan yang dapat memberikan prestasi sesuai dengan yang telah ditetapkan. Menurut Sondang P. Siagian ( $2007: 268$ ) Insentif dapat digolongkan pada dua kelompok utama, yaitu sistem insentif pada tingkat individual meliputi " piecework " bonus produksi, komisi, kurva " kematangan " dan Insentif, pada tingkat kelompok yang meliputi antara lain: insentif produksi, bagi keuntungan pengurangan biaya.

Tujuan utama dari pemberian Insentif kepada Karyawan pada dasarnya adalah untuk memotivasi mereka agar bekerja lebih baik dan dapat menunjukkan prestasi yang baik. Cara seperti ini adalah cara yang sangat efektif untuk meningkatkan hasil produksi perusahaan. Menurut pendapat Heidjrachman dan Husnan (blog Gecko dan fly : 2009 ) mengatakan bahwa pelaksanaan sistem upah insentif ini dimaksudkan perusahaan, untuk meningkatkan produktivitas kerja karyawan dan mempertahankan karyawan yang berprestasi untuk tetap berada dalam perusahaan.

Bagi Perusahaan tujuan pelaksanaan pemberian insentif kepada karyawan dimaksudkan untuk meningkatkan produksi dengan cara mendorong mereka agar bekerja disiplin dan semangat yang lebih tinggi dengan tujuan menghasilkan kualitas produksi yang lebih baik serta dapat bekerja dengan menggunakan faktor produksi 
seefisien dan seefektif mungkin. Bagi Karyawan dengan pemberian Insentif dari perusahaan maka diharapkan karyawan memperoleh banyak keuntungan, seperti misalnya mendapatkan bonus Insentif yang lebih besar, serta dorongan untuk mengembangkan diri.

Ada dua macam model Insentif yang diterapkan, yaitu financial Insentif dan non financial Insentif. Financial Insentif adalah Insentif yang dinilai dengan uang, misalnya upah dan gaji lebih, rekreasi, jaminan hari tua dan lain sebagainya. Sedangkan non financial insentif adalah insentif yang tidak dapat dinilai dengan uang, misalnya jam kerja, hubungan dengan atasan dan lain sebagainya. Sarwoto (1977 : 155-159) membedakan insentif dalam dua garis besar, yaitu insentif material dan insentif non material.

1. Insentif material

Insentif ini dapat diberikan dalam bentuk uang dan jaminan sosial. Insentif dalam bentuk uang dapat berupa :

a) Bonus

b) Uang yang diberikan sebagai balas jasa atas hasil kerja yang telah dilaksanakan.

* Diberikan secara selektif dan khusus kepada pegawai yang berhak menerima.

* Diberikan secara sekali terima tanpa suatu ikatan dimasa yang akan datang.

* Dalam perusahaan yang menggunakan sistem insentif ini lazimnya beberapa persen dari laba yang melebihi jumlah tertentu yang dimasukkan ke dalam sebuah dana bonus kemudian jumlah tersebut dibagi-bagi antara pihak yang akan diberikan bonus

2. Insentif non material

Insentif non material dapat diberikan dalam berbagai bentuk, yaitu Pemberian pujian lisan maupun tulisan secara resmi (di depan umum) ataupun secara pribadi, Ucapan terima kasih secara formal maupun informal, Pemberian hak untuk menggunakan atribut jabatan, Pemberian perlengkapan khusus pada ruangan kerja.

\section{Pengertian Kompensasi}

Karyawan umumnya selalu menjadikan kompensasi sebagai tujuan utama dalam berkerja. Kompensasi sebenarnya bukan sesuatu hal yang baru karena cukup kompleks masalah ini. Di negara industripun yang sudah maju masalah kompensasi selalu muncul yang berakhir dengan pemogokan dan sering kali terjadi kerusuhan. Kompensasi berkembang sesuai dengan perubahan disegala aspek kehidupan. Keadaan perekonomian suatu Negara sangat menentukan tingkat pemberian kompensasi kepada karyawan. Pemberian kompensasi yang layak karena bersifat adil dan manusiawi akan memicu semangat Kinerja Karyawan dalam kegiatan produksi sehingga operasional perusahaan dapat berdaya guna dan berhasil guna. Menurut Soekidjo Notoatmodjo ( 2003 : 153 ) Kompensasi adalah segala sesuatu yang diterima oleh karyawan sebagai balas jasa untuk kerja mereka. Pengertian lain dari kompensasi yang di kemukakan oleh penulis Alex S. Nitisemito ( 1986 : 149 ) yaitu : Kompensasi adalah merupakan balasan yang diberikan oleh perusahaan kepada karyawan dalam hal ini yakni upah atau gaji yang dapat dinilai dengan uang dan mempunyai kecenderungan diberikan tetap. Dari uraian tersebut diatas dapat memberikan penegrtian dari kompensasi yang baru lagi di 
antaranya yaitu : Imbalan yang diberikan secara berkala dan berbentuk uang dengan nominal yang telah ditetapkan dan dapat dirasakan dan memberikan manfaat langsung bagi para karyawan. Faktor-faktor yang mempengaruhi kompensasi Soekidjo Notoatmodjo ( 2003 : 153 ) menjelaskan sejumlah faktor yang menentukan besar kecilnya pemberian kompensasi adalah :

1. Produktivitas / kinerja adalah suatu kontribusi yang dilakukan oleh karyawan dalam bekerja secara baik dan dapat diberikan kompensasi sesuai dari hasil kinerja yang mereka lakukan terhadap perusahaan.

2. Kemampuan untuk membayar pemberian kompensasi akan tergantung kepada kemampuan organisasi itu untuk membayar.

3. Kesediaan untuk membayar, kesediaan untuk membayar akan berpengaruh terhadap kebijaksanaan pemberian kopensasi kepada karyawannya.

4. Suplai dan permintaan tenaga kerja

5. Organisasi karyawan / serikat pekerja

6. Berbagai peraturan dan perundang- undangan

7. Biaya hidup

8. Pemerintah adalah sebuah institusi yang mengatur keseimbangan antara pekerja dan pemberi kerja, sehingga tercipta tingkat kompensasi yang wajar antara pekerja dan pemberi kerja.

Menurut T. Hani Handoko ( dalam Leli Suheti 2002 : 13 ) bahwa pemberian kompensasi oleh perusahaan kepada karyawan nya bertujuan untuk :

1. Memperoleh sumber daya manusia yang memenuhi persyaratan pekerjaan.

2. Mempertahankan sumber daya manusia yang ada.

3. Menjamin keadilan

4. Menghargai perilaku yang diinginkan

5. Pengendalian biaya

6. Memenuhi peraturan - peraturan

\section{Pengertian Reward}

Secara bahasa reward diartikan sebagai ganjaran, hadiah, upah, penghargaan. Reward adalah sembarang perangsang, situasi atau pernyataan lisan yang bisa menghasilkan kepuasan atau menambah kemungkinan suatu perbuatan yang di pelajari. Dan ada juga pengertian lain dari reward itu sendiri, Reward dimunculkan untuk memotivasi seseorang karena ada anggapan bahwa dengan memberikan hadiah atas hasil pekerjaannya, ia akan bekerja lebih maksimal. Apalagi jika hadiah yang diberikan cukup menggiurkan. Menurut ( dalam blog Wibowo : 2003 ).

Sistem Reward Dalam Pandangan Teoritis Teori yang sangat berpengaruh dalam teori humanistik ini adalah Theory of Human Motivation yang dikembangkan oleh Abraham Maslow (1954). Maslow mengemukakan gagasan hirarki kebutuhan manusia, yang terbagi menjadi dua kelompok, yaitu deficiency needs dan growth needs. Deficiency needs meliputi (dari urutan paling bawah) kebutuhan fisiologis, kebutuhan rasa aman, kebutuhan akan cinta dan rasa memiliki, dan kebutuhan akan penghargaan. Dalam deficiency needs ini, kebutuhan yang lebih bawah harus dipenuhi lebih dulu sebelum ke kebutuhan di level berikutnya. Growth needs meliputi kebutuhan kognitif, 
kebutuhan estetik, kebutuhan aktualisasi diri. Menurut Maslow, manusia hanya dapat bergerak ke growth needs jika dan hanya jika deficiency needs sudah terpenuhi. Hirarki kebutuhan Maslow merupakan cara yang menarik untuk melihat hubungan antara motif manusia dan kesempatan yang disediakan oleh lingkungan (Atkinson, 1983). Tujuan dari reward juga adalah agar seseorang menjadi semakin giat dalam usaha memperbaiki atau meningkatkan prestasi dan kinerja yang telah dicapainya.

\section{Kinerja}

Dalam kutipan buku yang berjudul " Evaluasi Kinerja SDM “ yang di kutip oleh Selly Lovita, pengertian kinerja menurut pendapat A.A. Anwar Prabu Mangkunegara Kinerja Karyawan adalah hasil kerja secara kualitas dan kuantitas yang dicapai oleh seseorang karyawan dalam melaksanakan tugasnya sesuai dengan tanggung jawab yang diberikan kepadanya. ( Mangkunegara 2005 : 9 ). Berdasarkan pengertian yang dijabarkan diatas dapat di tafsirkan bahwa kinerja seorang karyawan erat kaitannya dengan hasil pekerjaan seseorang dalam suatu organisasi, hasil pekerjaan tersebut dapat menyangkut kualitas, kuantitas, dan ketepatan waktu. Kinerja karyawan tidak hanya dipengaruhi oleh kemampuan dan keahlian dalam bekerja, tetapi juga sangat dipengaruhi oleh semangat kerjanya. Faktor-faktor yang mempengaruhi kinerja karyawan menurut Simanjuntak ( 1995 : 14 ) dalam Astri Maharani faktor - faktor yang mempengaruhi kinerja karyawan antara lain :

1. Pendidikan dan pengalaman

2. Pembayaran serta penghasilan tambahan dari hasil evaluasi kinerja dan jaminan sosial lainnya

3. Keterampilan, kemampuan dan disiplin kerja

4. Gizi dan kesehatan

5. Lingkungan dan iklim kerja

6. Motivasi

7. Masa kerja

8. Penghargaan yang mendorong untuk bekerja lebih giat

Selain itu menurut Dewan Kinerja Nasional Indonesia dalam Leli Suheti (2002:19) menjelaskan bahwa faktor yang mempengaruhi kinerja karyawan adalah berdasarkan faktor internal dan faktor external, faktor-faktor tersebut sebagai berikut :

Faktor internal adalah

1. Tingkat pendidikan

2. Perbaikan penghasilan dan sistem pembayaran upah yang dapat menjamin perbaikan kesehatan.

3. Pemilihan teknologi dan sarana untuk produksi.

4. Peningkatan kemampuan manajerial pimpinan.

5. Pemberian kesempatan baik untuk pekerja dalam pekerjaan yang sesuai dengan pendidikan dan keterampilan.

6. Penghasilan dan penghargaan mendorong untuk bekerja secara giat

7. Tingkat disiplin kerja.

8. Jaminan sosial lainnya. 
Faktor external adalah

1. Serikat pekerja

2. Peraturan pemerintah

3. Keadaan perekonomian.

\section{Kerangka Pemikiran}

Secara skematis pengaruh insentif, kompensasi, dan reward terhadap kinerja karyawan PT. Bank Rakyat Indonesia (Persero). Tbk Kantor Cabang Bengkulu dapat digambarkan dalam kerangka sebagai berikut :

\section{GAMBAR I. \\ KERANGKA PEMIKIRAN}

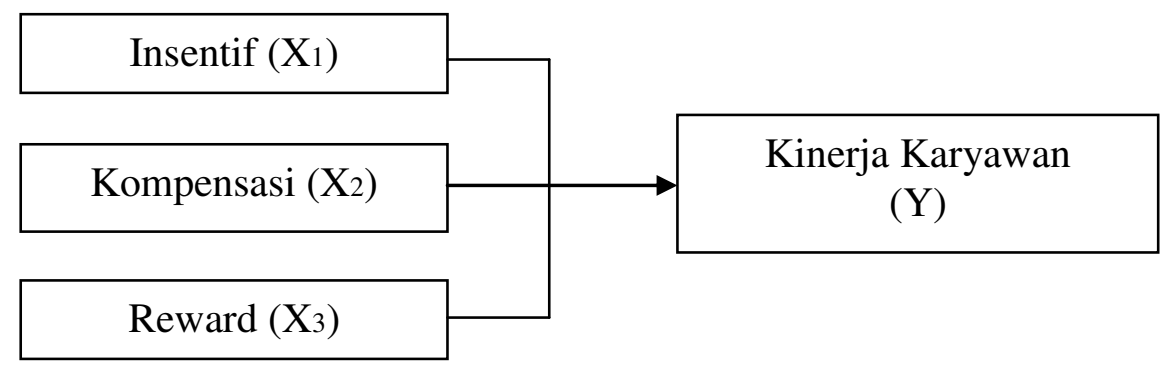

\section{HASIL PENELITIAN DAN PEMBAHASAN}

Gambaran Umum PT. Bank Rakyat Indonesia (Persero) Tbk.

PT.Bank Rakyat Indonesia memiliki banyak sejarah yang cukup luas mulai dari awal perkembangan, seiring dengan kemajuan zaman. Bank Rakyat Indonesia didirikan dengan peraturan pemerintah (PP) no. 1 tahun 1946 tanggal 22 februari 1946. Bank Rakyat Indonesia berasal dari "The Algemere Folk Seredit Bank"(AFB) yang dalam masa pendudukan jepang bernama Syomin Giriko. Berdasarkan UU no.14 tahun 1967, Bank Rakyat Indonesia ( BRI ) termasuk dalam kategori Bank Umum. Berdasarkan UU no.42 tahun 1960 dan UU no.43 Prp tahun 1960 . Bank Rakyat Indonesia merupakan peleburan dari Bank Tani dan Nelayan yang didirikan berdasarkan UU no.41 Prp . tahun 1960. Melalui keputusan Menteri Keuangan no.26/206/B.U.M/11 tanggal 30 november 1960 terjadi lagi peleburan bank yang telah dinasionalisir yaitu " Nederlansche Handel Mantschappih" (nasionalisasi melalui pp.no.44 tahun 1960) kedalam Bank Koperasi Tani dan Nelayan. Kemudian berdasarkan penetapan presiden no.9 tahun 965 Bank Koperasi Tani dan Nelayan dan Eks NHM dilebur kedalam Bank Indonesia. Menjadi Bank Indonesia Urusan Koperasi, Tani dan Nelayan. Selanjutnya berdasarkan penetapan presiden no.17 tahun 1965 eks Bank Koperasi,Tani dan Nelayan.(BI urusan Koperasi Tani dan Nelayan dilebur kedalam Bank Tunggal Bank Negra Indonesia). Dan menjalankan usahanya dengan nama Bank Nasional Indonesia ( BNI ) unit II. Dalam kegiatan sehari-hari eks peleburan BRI dengan Bank Tani dan Nelayan bekerja dengan nama BNI unit II Rural, sedangkan Nederlansche Handel Mantscha (NHM) bekerja dengan nama BNI unit II Bidang Eksim. 


\section{CREATIVE RESEARCH MANAGEMENT JOURNAL-CRMJ Juli}

Berdasarkan UU no.14 tahun 1967 dan UU no.13 tahun 1968, BNI unit II Rural dan Eksim dipisah menjadi Bank Milik Negara dengan nama

1. BRI yang menampung segala hak dan kewajiban serta kekayaan dan kelengkapan BNI Unit II Bidang Rural, dengan UU no.21 tahun 1968.

2. Bank Eksport Indonesia yang menampung segala hak dan kewajiban serta kekayaan dan perlengkapan BNI Unit II Bidang Eksport Import(Eksim), dengan UU no.22 tahun 1968.

Sampai saat ini BRI dalam manajemen pelaksanaan dan pengolahannya terlihat kian mantap, ini dapat dilihat dari semakin berkembangnya cabang - cabang dan unit - unit dari PT. Bank Rakyat Indonesia ( Persero ). Tbk itu sendiri, Dikota Bengkulu terdapat 1 (satu) kantor cabang yang beralamatkan jalan S.Parman No.30 Kelurahan Padang Jati Kecamatan Ratu Agung Kota Bengkulu Provinsi Bengkulu, memiliki 12 Kantor Unit BRI dan 3 Kantor Kas BRI serta Mobil Keliling BRI. Adapun kantor-kantor unit Bank Rakyat Indonesia dibengkulu sebagai berikut:

1. Kantor Unit BRI Padang jati

2. Kantor Unit BRI Gading Cempaka

3. Kantor Unit BRI Padang Harapan

4. Kantor Unti BRI Pagar Dewa

5. Kantor Unit BRI Betungan

6. Kantor Unit BRI Pulau Baii

7. Kantor Unit BRI Muara Bangkahulu

8. Kantor Unit BRI Lingkar timur

9. Kantor Unit BRI Ratu Samban

10. Kantor Unit BRI Tapak Paderi

11. Kantor Unit BRI Rawa Makmur

12. Kantor Unit BRI Mega Mall Bengkulu

13. KCP(Kantor Cabang Pembantu) Rafflesia

14. Kantor Kas Unib,BIM(Bengcoolen)

15. Teras Pagar dewa,Pasar Minggu,Barukoto

16. Mobil Kas Keliling

Manajemen PT. Bank Rakyat Indonesia (Persero) Tbk Cabang Bengkulu

Manajemen PT.BRI Kantor cabang Bengkulu dipimpin oleh 1(satu) orang pemimpin cabang dan memiliki wewenang mengatur baik berupa kinerja dan segala bentuk yang berkaitan dengan perkembangan serta kemajuan semua unit kerja PT. BRI (persero). Tbk yang terdapat dikota Bengkulu sebanyak 12 Unit,1 KCP, 2 Kantor Kas, 3 Teras BRI. Selain itu pemimpin cabang dibantu oleh beberapa bagian sebagai berikut:

1. Pincapem (Pemimpin Cabang Pembantu) lokasi KCP

2. MP (Manager Pemasaran) kantor Cabang BRI

3. AMBM (Asisstant Manager Bagian Mikro) megkoordinir semua unit

4. AMO (Assitant Manager Operasional) kantor cabang BRI

5. SPI/SPO/SDM (Supervisor Pelayanan Intern/Operasional/Sumber Daya)

6. SPV.ADK (Supervisor Admin Kredit)

7. SPV.DJS 
8. Komisaris dan para direksi berkedudukan di kantor pusat Jakarta,dan untuk kanwil induk Palembang menjadi regional Sumatera bagian Selatan. Kantor BRI persero Tbk Cabang Bangkulu Menjadi Kantor Koordinator Wilayah Cluster Bengkulu.

\section{Karakteristik Responden}

Umur Responden

Dilihat dari umur responden penelitian, maka sebagian besar karyawan PT. Bank Rakyat Indonesia (Persero). Tbk Cabang Bengkulu, yaitu 30 orang berumur antara 20 tahun sampai dengan 30 tahun

TABEL I.

\section{JUMLAH DAN PERSENTASE KARYAWAN}

BERDASARKAN UMUR

\begin{tabular}{|c|l|c|c|}
\hline No & Umur Karyawan PT.BRI Cab Bengkulu & Jumlah & Persentase \\
\hline 1 & Dibawah 20 Tahun & 0 & 0 \\
2 & 20 Tahun s/d 30 Tahun & 30 & $60 \%$ \\
3 & 31 Tahun s/d 40 Tahun & 12 & $24 \%$ \\
4 & 41 Tahun s/d 50 Tahun & 5 & $10 \%$ \\
5 & Lebih dari 50 Tahun & 3 & $6 \%$ \\
\hline \multicolumn{2}{|c|}{ Jumlah/Total } & 50 & $100 \%$ \\
\hline
\end{tabular}

Sumber : Hasil Data Pekerja PT.BRI Bengkulu Diolah, 2013

\section{Pendidikan Responden}

Dilihat dari pendidikan responden penelitian, maka sebagian besar karyawan PT. Bank Rakyat Indonesia (Persero). Tbk Cabang Bengkulu, berpendidikan sarjana (S1) yaitu 42 orang.

TABEL II.

JUMLAH DAN PERSENTASE KARYAWAN BERDASARKAN PENDIDIKAN

\begin{tabular}{|c|l|c|c|}
\hline No & \multicolumn{1}{|c|}{ Pendidikan } & Jumlah & Persentase \\
\hline 1 & SD atau sederajat & 0 & 0 \\
2 & SLTP atau sederajat & 0 & 0 \\
3 & SLTA/SMA atau sederajat & 4 & $8 \%$ \\
4 & Diploma 1,2,3 (D1),(D2),(D3) & 2 & $4 \%$ \\
5 & Sarjana (S1) & 42 & $84 \%$ \\
6 & Pasca Sarjana (S2) & 2 & $8 \%$ \\
7 & Doktor (S3) & 0 & 0 \\
\hline \multicolumn{2}{|c|}{ Jumlah/Total } & 50 & $100 \%$ \\
\hline
\end{tabular}

Sumber : Hasil Data Pekerja PT.BRI Bengkulu Diolah, 2013 


\section{Masa Kerja Responden}

Dilihat dari umur masa kerja, maka sebagian besar karyawan PT. Bank Rakyat Indonesia (Persero). Tbk Cabang Bengkulu, sudah bekerja selama kurang dari 2 tahun dan $>$ dari 3 tahun s/d 7 tahun bekerja.

TABEL III.

JUMLAH DAN PERSENTASE KARYAWAN BERDASARKAN MASA KERJA

\begin{tabular}{|c|l|c|c|}
\hline No & Masa Kerja Karyawan PT.BRI Cab Bengkulu & Jumlah & Persentase \\
\hline 1 & 0 Tahun & 0 & 0 \\
2 & Kurang < 2 Tahun & 19 & $38 \%$ \\
3 & 3 Tahun s/d 7 Tahun & 15 & $30 \%$ \\
4 & 8 Tahun s/d 11 Tahun & 7 & $14 \%$ \\
5 & Lebih dari > 11 Tahun keatas & 9 & $18 \%$ \\
\hline \multicolumn{2}{|r|}{ Jumlah/Total } & 50 & $100 \%$ \\
\hline
\end{tabular}

Sumber : Hasil Data Pekerja PT.BRI Bengkulu Diolah, 2013

Tanggapan Responden Terhadap Variabel Insentif

Dari kuesioner yang diberikan kepada 50 orang karyawan PT. Bank Rakyat Indonesia (Persero). Tbk Cabang Bengkulu, maka diperoleh data tentang tanggapan mereka terhadap insentif. Berikut ini merupakan data mengenai jumlah skor dan persentase tanggapan responden terhadap indikator variabel Insentif yang terbagi dalam 5 pernyataan.

TABEL IV.

PERNYATAAN RESPONDEN TERHADAP INSENTIF

\begin{tabular}{|c|c|c|c|c|c|c|}
\hline \multirow[b]{2}{*}{ Pernyataan } & \multicolumn{5}{|c|}{ Skor dan Persentase } & \multirow[b]{2}{*}{ Jumlah } \\
\hline & $\begin{array}{c}\text { SS } \\
5\end{array}$ & $\begin{array}{l}S \\
4\end{array}$ & $\begin{array}{c}\text { CS } \\
\mathbf{3}\end{array}$ & $\begin{array}{c}\text { TS } \\
2\end{array}$ & $\begin{array}{c}\text { STS } \\
1\end{array}$ & \\
\hline 1 & $\begin{array}{c}21 \\
(42 \%)\end{array}$ & $\begin{array}{c}24 \\
(48 \%)\end{array}$ & $\begin{array}{c}4 \\
(8 \%)\end{array}$ & $\begin{array}{c}1 \\
(2 \%)\end{array}$ & $\begin{array}{c}0 \\
(0 \%)\end{array}$ & $\begin{array}{c}50 \\
100 \%\end{array}$ \\
\hline 2 & $\begin{array}{c}4 \\
(8 \%)\end{array}$ & $\begin{array}{c}20 \\
(40 \%)\end{array}$ & $\begin{array}{c}15 \\
(30 \%)\end{array}$ & $\begin{array}{c}9 \\
(18 \%)\end{array}$ & $\begin{array}{c}2 \\
(4 \%)\end{array}$ & $\begin{array}{c}50 \\
100 \%\end{array}$ \\
\hline 3 & $\begin{array}{c}3 \\
(6 \%) \\
\end{array}$ & $\begin{array}{c}17 \\
(34 \%) \\
\end{array}$ & $\begin{array}{c}16 \\
(32 \%) \\
\end{array}$ & $\begin{array}{c}11 \\
(22 \%) \\
\end{array}$ & $\begin{array}{c}3 \\
(6 \%) \\
\end{array}$ & $\begin{array}{c}50 \\
100 \% \\
\end{array}$ \\
\hline 4 & $\begin{array}{c}9 \\
(18 \%)\end{array}$ & $\begin{array}{c}21 \\
(42 \%)\end{array}$ & $\begin{array}{c}11 \\
(22 \%)\end{array}$ & $\begin{array}{c}9 \\
(18 \%)\end{array}$ & $\begin{array}{c}0 \\
(0 \%)\end{array}$ & $\begin{array}{c}50 \\
100 \%\end{array}$ \\
\hline 5 & $\begin{array}{c}8 \\
(16 \%) \\
\end{array}$ & $\begin{array}{c}33 \\
(66 \%) \\
\end{array}$ & $\begin{array}{c}9 \\
(18 \%)\end{array}$ & $\begin{array}{c}0 \\
(0 \%)\end{array}$ & $\begin{array}{c}0 \\
(0 \%)\end{array}$ & $\begin{array}{c}50 \\
100 \% \\
\end{array}$ \\
\hline
\end{tabular}

Sumber : Hasil Penelitian Diolah, 2013

Pada pernyataan pertama yang menyatakan bahwa PT. BRI akan memberikan Insentif/bonus sesuai dengan peraturan perusahaan. Dari pernyataan tersebut sebanyak $42 \%$ dari responden menyatakan sangat setuju, $48 \%$ menyatakan setuju dan $2 \%$ yang 


\section{CREATIVE RESEARCH MANAGEMENT JOURNAL-CRMJ Juli}

menyatakan tidak setuju. Dari pernyataan tersebut dapat disimpulkan bahwa para karyawan mendapatkan Insentif/bonus diberikan sesuai dengan peraturan PT. BRI.

Pada pernyataan kedua yang menyatakan bahwa sangat mudah dan dapat dilakukan dengan cepat oleh pihak perusahaan untuk memperoleh insentif/bonus. Dari pernyataan tersebut sebanyak $8 \%$ dari responden menyatakan sangat setuju, $40 \%$ menyatakan setuju dan $18 \%$ yang menyatakan tidak setuju. Dari pernyataan tersebut dapat disimpulkan bahwa sangat mudah dan dapat dilakukan dengan cepat oleh pihak perusahaan untuk memperoleh Insentif/bonus.

Pada pernyataan ketiga yang menyatakan bahwa Insentif/bonus diberikan tepat waktu sesuai dengan peraturan perusahaan. Dari pernyataan tersebut sebanyak $6 \%$ dari responden menyatakan sangat setuju, 34\% menyatakan setuju dan $22 \%$ yang menyatakan tidak setuju. Dari pernyataan tersebut dapat disimpulkan bahwa para karyawan Insentif/Bonus diberikan tepat waktu sesuai dengan peraturan perusahaan.

Pada pernyataan keempat yang menyatakan bahwa jumlah insentif/bonus yang diberikan sesuai dengan hasil kerja karyawan. Dari pernyataan tersebut sebanyak $18 \%$ dari responden menyatakan sangat setuju, $42 \%$ menyatakan setuju dan $18 \%$ yang menyatakan tidak setuju. Dari pernyataan tersebut dapat disimpulkan bahwa para karyawan mendapatkan jumlah insentif/bonus yang diberikan sesuai dengan hasil kerja karyawan

Pada pernyataan kelima yang menyatakan bahwa bersemangat, bekerja keras dan penuh vitalitas dalam pencapaian target agar insentif/bonus didapatkan besar. Dari pernyataan tersebut sebanyak $16 \%$ dari responden menyatakan sangat setuju, $66 \%$ menyatakan setuju dan 0\% yang menyatakan tidak setuju. Dari pernyataan tersebut dapat disimpulkan bahwa para karyawan bersemangat, bekerja keras dan penuh vitalitas dalam pencapaian target agar insentif/bonus didapatkan besar.

\section{Tanggapan Responden Terhadap Variabel Kompensasi}

Dari hasil penelitian dengan mengumpulkan jawaban kuesioner yang disampaikan kepada karyawan PT.BRI Cabang Bengkulu, maka diperoleh data tanggapan atas pernyataan yang ada dikuesioner. Berikut ini merupakan data skor dan persentase tanggapan responden terhadap variabel kompensasi. 
TABEL V.

PERNYATAAN RESPONDEN TERHADAP KOMPENSASI

\begin{tabular}{|c|c|c|c|c|c|c|}
\hline \multirow[b]{2}{*}{ Pernyataan } & \multicolumn{5}{|c|}{ Skor dan Persentase } & \multirow[b]{2}{*}{ Jumlah } \\
\hline & $\begin{array}{c}S S \\
5\end{array}$ & $\begin{array}{l}S \\
4\end{array}$ & $\begin{array}{c}\mathrm{CS} \\
3\end{array}$ & $\begin{array}{c}\text { TS } \\
2\end{array}$ & $\begin{array}{c}\text { STS } \\
1\end{array}$ & \\
\hline 1 & $\begin{array}{c}4 \\
(8 \%)\end{array}$ & $\begin{array}{c}17 \\
(34 \%)\end{array}$ & $\begin{array}{c}24 \\
(48 \%)\end{array}$ & $\begin{array}{c}5 \\
(10 \%)\end{array}$ & $\begin{array}{c}0 \\
(0 \%)\end{array}$ & $\begin{array}{c}50 \\
(100 \%)\end{array}$ \\
\hline 2 & $\begin{array}{c}6 \\
(12 \%)\end{array}$ & $\begin{array}{c}30 \\
(6 \%)\end{array}$ & $\begin{array}{c}11 \\
(22 \%)\end{array}$ & $\begin{array}{c}3 \\
(6 \%)\end{array}$ & $\begin{array}{c}0 \\
(0 \%)\end{array}$ & $\begin{array}{c}50 \\
(100 \%)\end{array}$ \\
\hline 3 & $\begin{array}{c}16 \\
(32 \%) \\
\end{array}$ & $\begin{array}{c}23 \\
(46 \%) \\
\end{array}$ & $\begin{array}{c}4 \\
(8 \%) \\
\end{array}$ & $\begin{array}{c}5 \\
(10 \%) \\
\end{array}$ & $\begin{array}{c}2 \\
(4 \%) \\
\end{array}$ & $\begin{array}{c}50 \\
(100 \%) \\
\end{array}$ \\
\hline 4 & $\begin{array}{c}3 \\
(6 \%)\end{array}$ & $\begin{array}{c}20 \\
(4 \%)\end{array}$ & $\begin{array}{c}17 \\
(34 \%)\end{array}$ & $\begin{array}{c}10 \\
(2 \%)\end{array}$ & $\begin{array}{c}0 \\
(0 \%)\end{array}$ & $\begin{array}{c}50 \\
(100 \%) \\
\end{array}$ \\
\hline 5 & $\begin{array}{c}3 \\
(6 \%)\end{array}$ & $\begin{array}{c}24 \\
(0,48 \%)\end{array}$ & $\begin{array}{c}12 \\
(24 \%)\end{array}$ & $\begin{array}{c}10 \\
(2 \%)\end{array}$ & $\begin{array}{c}1 \\
(2 \%)\end{array}$ & $\begin{array}{c}50 \\
(100 \%)\end{array}$ \\
\hline
\end{tabular}

Sumber : Hasil Penelitian Diolah, 2013

Pada pernyataan pertama yang menyatakan bahwa Kompensasi (Gaji) yang dibayarkan sudah memenuhi kebutuhan hidup. Dari pernyataan tersebut sebanyak $8 \%$ dari responden menyatakan sangat setuju, 34\% menyatakan setuju,persentase besar didominasi dengan skor $48 \%$ responden menjawab cukup setuju dan $5 \%$ yang menyatakan tidak setuju. Dari pernyataan tersebut dapat disimpulkan bahwa para karyawan cukup setuju dengan Kompensasi (Gaji) yang dibayarkan sudah memenuhi kebutuhan hidup

Pada pernyataan kedua yang menyatakan bahwa berkenan menerima jumlah kompensasi (gaji) yang dibayarkan pihak perusahaan saat sekarang ini. Dari pernyataan tersebut sebanyak $12 \%$ dari responden menyatakan sangat setuju, $60 \%$ menyatakan setuju dan $6 \%$ yang menyatakan tidak setuju. Dari pernyataan tersebut dapat disimpulkan bahwa para karyawan berkenan menerima jumlah kompensasi (gaji) yang dibayarkan pihak perusahaan saat sekarang ini .

Pada pernyataan ketiga yang menyatakan bahwa kompensasi (gaji) diberikan tepat waktu sesuai dengan peraturan perusahaan. Dari pernyataan tersebut sebanyak $32 \%$ dari responden menyatakan sangat setuju, $46 \%$ menyatakan setuju dan $10 \%$ yang menyatakan tidak setuju. Dari pernyataan tersebut dapat disimpulkan bahwa para karyawan setuju kompensasi (gaji) diberikan tepat waktu sesuai dengan peraturan perusahaan.

Pada pernyataan keempat yang menyatakan bahwa setiap tahun peningkatan kompensasi sudah menjamin biaya hidup masa depan. Dari pernyataan tersebut sebanyak $6 \%$ dari responden menyatakan sangat setuju, $40 \%$ menyatakan setuju dan $20 \%$ yang menyatakan tidak setuju. Dari pernyataan tersebut dapat disimpulkan bahwa para karyawan setuju dengan setiap tahun peningkatan kompensasi sudah menjamin biaya hidup masa depan .

Pada pernyataan kelima yang menyatakan bahwa kesejahteraan hidup yang diberikan oleh perusahaan Dengan kompensasi (gaji) telah anda terima, dan ada 
tambahan penghasilan lain dari tempat kerja. Dari pernyataan tersebut sebanyak $6 \%$ dari responden menyatakan sangat setuju, $48 \%$ menyatakan setuju dan $20 \%$ yang menyatakan tidak setuju. Dari pernyataan tersebut dapat disimpulkan bahwa para karyawan kesejahteraan hidup yang diberikan oleh perusahaan dengan kompensasi (gaji) telah anda terima, dan telah terpenuhi.

\section{Tanggapan Responden Terhadap Variabel Reward}

Dari hasil penelitian dengan mengumpulkan jawaban kuesioner yang disampaikan kepada karyawan PT.BRI Cabang Bengkulu, maka diperoleh data tanggapan atas pernyataan yang ada dikuesioner. Berikut ini merupakan data skor dan persentase tanggapan responden terhadap variabel Reward.

TABEL VI.

PERNYATAAN RESPONDEN TERHADAP REWARD

\begin{tabular}{|c|c|c|c|c|c|c|}
\hline \multirow[b]{2}{*}{ Pernyataan } & \multicolumn{5}{|c|}{ Skor dan Persentase } & \multirow[b]{2}{*}{ Jumlah } \\
\hline & $\begin{array}{c}\text { SS } \\
5\end{array}$ & $\begin{array}{l}S \\
4\end{array}$ & $\begin{array}{c}\text { CS } \\
3\end{array}$ & $\begin{array}{c}\text { TS } \\
2\end{array}$ & $\begin{array}{c}\text { STS } \\
1\end{array}$ & \\
\hline 1 & $\begin{array}{c}8 \\
(16 \%)\end{array}$ & $\begin{array}{c}16 \\
(32 \%)\end{array}$ & $\begin{array}{c}22 \\
(44 \%)\end{array}$ & $\begin{array}{c}4 \\
(8 \%)\end{array}$ & $\begin{array}{c}0 \\
(0 \%)\end{array}$ & $\begin{array}{c}50 \\
(100 \%)\end{array}$ \\
\hline 2 & $\begin{array}{c}4 \\
(8 \%) \\
\end{array}$ & $\begin{array}{c}23 \\
(46 \%) \\
\end{array}$ & $\begin{array}{c}14 \\
(28 \%) \\
\end{array}$ & $\begin{array}{c}9 \\
(18 \%) \\
\end{array}$ & $\begin{array}{c}0 \\
(0 \%) \\
\end{array}$ & $\begin{array}{c}50 \\
(100 \%) \\
\end{array}$ \\
\hline 3 & $\begin{array}{c}7 \\
(14 \%) \\
\end{array}$ & $\begin{array}{c}30 \\
(6 \%) \\
\end{array}$ & $\begin{array}{c}9 \\
(18 \%) \\
\end{array}$ & $\begin{array}{c}4 \\
(8 \%)\end{array}$ & $\begin{array}{c}0 \\
(0 \%)\end{array}$ & $\begin{array}{c}50 \\
(100 \%) \\
\end{array}$ \\
\hline 4 & $\begin{array}{c}9 \\
(18 \%)\end{array}$ & $\begin{array}{c}24 \\
(48 \%)\end{array}$ & $\begin{array}{c}15 \\
(3 \%)\end{array}$ & $\begin{array}{c}3 \\
(6 \%)\end{array}$ & $\begin{array}{c}0 \\
(0 \%)\end{array}$ & $\begin{array}{c}50 \\
(! 00 \%)\end{array}$ \\
\hline 5 & $\begin{array}{c}9 \\
(18 \%)\end{array}$ & $\begin{array}{c}24 \\
(48 \%)\end{array}$ & $\begin{array}{c}14 \\
(28 \%)\end{array}$ & $\begin{array}{c}1 \\
(2 \%)\end{array}$ & $\begin{array}{c}0 \\
(0 \%)\end{array}$ & $\begin{array}{c}50 \\
(100 \%)\end{array}$ \\
\hline
\end{tabular}

Sumber : Hasil Penelitian Diolah, 2013

Pada pernyataan pertama yang menyatakan bahwa prestasi yang diraih dalam pekerjaan masing - masing bagian serta pengabdian selalu diperhatikan pihak perusahaan. Dari pernyataan tersebut sebanyak $16 \%$ dari responden menyatakan sangat setuju, 32\% menyatakan setuju, didomonasi jawaban responden cukup setuju dengan persentase sebesar $44 \%$ dan $8 \%$ yang menyatakan tidak setuju. Dari pernyataan tersebut dapat disimpulkan bahwa para karyawan setuju dengan pernyataan prestasi yang diraih dalam pekerjaan masing - masing bagian serta pengabdian selalu diperhatikan pihak perusahaan.

Pada pernyataan kedua yang menyatakan bahwa masa kerja yang relative lama,sudah pasti mempunyai peningkatan kinerja yang lebih baik. Dari pernyataan tersebut sebanyak $8 \%$ dari responden menyatakan sangat setuju, $46 \%$ menyatakan setuju dan $18 \%$ yang menyatakan tidak setuju. Dari pernyataan tersebut dapat disimpulkan bahwa para karyawan setuju masa kerja yang relative lama, sudah pasti mempunyai peningkatan kinerja yang lebih baik. 


\section{CREATIVE RESEARCH MANAGEMENT JOURNAL-CRMJ Juli}

Pada pernyataan ketiga yang menyatakan bahwa pemberian Reward, di PT. Bank Rakyat Indonesia sudah menjadi motivasi berprestasi bagi seluruh karyawannya. Dari pernyataan tersebut sebanyak $14 \%$ dari responden menyatakan sangat setuju, $60 \%$ menyatakan setuju dan $8 \%$ yang menyatakan tidak setuju. Dari pernyataan tersebut dapat disimpulkan bahwa para karyawan setuju pemberian Reward, di PT. Bank Rakyat Indonesia sudah menjadi motivasi berprestasi bagi seluruh karyawannya.

Pada pernyataan keempat yang menyatakan bahwa integritas, loyalitas, tanggung jawab, serta propesionalitas menjadi dasar penilaian untuk mendapatkan reward. Dari pernyataan tersebut sebanyak $18 \%$ dari responden menyatakan sangat setuju, $48 \%$ menyatakan setuju dan $6 \%$ yang menyatakan tidak setuju. Dari pernyataan tersebut dapat disimpulkan bahwa para karyawan setuju integritas, loyalitas, tanggung jawab, serta propesionalitas. menjadi dasar penilaian untuk mendapatkan reward. Pada pernyataan kelima yang menyatakan bahwa perbedaan reward yang diberikan, berdasarkan hasil penilaian masing - masing kinerja selama masa kerja. Dari pernyataan tersebut sebanyak $18 \%$ dari responden menyatakan sangat setuju, $48 \%$ menyatakan setuju dan $2 \%$ yang menyatakan tidak setuju. Dari pernyataan tersebut dapat disimpulkan para karyawan setuju dengan perbedaan reward yang diberikan, berdasarkan hasil penilaian masing - masing kinerja selama masa kerja.

\section{Tanggapan Responden Terhadap Variabel Kinerja Karyawan}

Dari hasil penelitian dengan mengumpulkan jawaban kuesioner yang disampaikan kepada karyawan PT. BRI Cabang Bengkulu, maka diperoleh data tanggapan atas pernyataan yang ada dikuesioner. Berikut ini merupakan data skor dan persentase tanggapan responden terhadap variabel Kinerja Karyawan.

TABEL VII.

PERNYATAAN RESPONDEN TERHADAP KINERJA KARYAWAN

\begin{tabular}{|c|c|c|c|c|c|c|}
\hline \multirow[b]{2}{*}{ Pernyataan } & \multicolumn{5}{|c|}{ Skor dan Persentase } & \multirow[b]{2}{*}{ Jumlah } \\
\hline & $\begin{array}{c}\text { SS } \\
5\end{array}$ & $\begin{array}{l}S \\
4\end{array}$ & $\begin{array}{c}\text { CS } \\
3\end{array}$ & $\begin{array}{c}\text { TS } \\
2\end{array}$ & $\begin{array}{c}\text { STS } \\
1\end{array}$ & \\
\hline 1 & $\begin{array}{c}10 \\
(2 \%)\end{array}$ & $\begin{array}{c}30 \\
(6 \%)\end{array}$ & $\begin{array}{c}10 \\
(2 \%)\end{array}$ & $\begin{array}{c}0 \\
(0 \%)\end{array}$ & $\begin{array}{c}0 \\
(0 \%)\end{array}$ & $\begin{array}{c}50 \\
(100 \%)\end{array}$ \\
\hline 2 & $\begin{array}{c}6 \\
(12 \%) \\
\end{array}$ & $\begin{array}{c}28 \\
(56 \%) \\
\end{array}$ & $\begin{array}{c}14 \\
(28 \%) \\
\end{array}$ & $\begin{array}{c}2 \\
(4 \%) \\
\end{array}$ & $\begin{array}{c}0 \\
(0 \%) \\
\end{array}$ & $\begin{array}{c}50 \\
(100 \%) \\
\end{array}$ \\
\hline 3 & $\begin{array}{c}6 \\
(12 \%)\end{array}$ & $\begin{array}{c}34 \\
(68 \%)\end{array}$ & $\begin{array}{c}7 \\
(14 \%)\end{array}$ & $\begin{array}{c}3 \\
(6 \%)\end{array}$ & $\begin{array}{c}0 \\
(0 \%)\end{array}$ & $\begin{array}{c}50 \\
(100 \%)\end{array}$ \\
\hline 4 & $\begin{array}{c}6 \\
(12 \%)\end{array}$ & $\begin{array}{c}34 \\
(68 \%)\end{array}$ & $\begin{array}{c}7 \\
(14 \%)\end{array}$ & $\begin{array}{c}3 \\
(6 \%)\end{array}$ & $\begin{array}{c}0 \\
(0 \%)\end{array}$ & $\begin{array}{c}50 \\
(! 00 \%)\end{array}$ \\
\hline 5 & 7 & $\begin{array}{c}26 \\
(52 \%)\end{array}$ & $\begin{array}{c}15 \\
(3 \%)\end{array}$ & $\begin{array}{c}2 \\
(4 \%)\end{array}$ & $\begin{array}{c}0 \\
(0 \%)\end{array}$ & $\begin{array}{c}50 \\
(100 \%)\end{array}$ \\
\hline
\end{tabular}

Sumber : Hasil Penelitian Diolah, 2013

Pada pernyataan pertama yang menyatakan bahwa pekerjaan dapat diselesaikan dengan rasa tanggung jawab, serta tepat pada waktu yang telah ditentukan. Dari 
pernyataan tersebut sebanyak $20 \%$ dari responden menyatakan sangat setuju, $60 \%$ menyatakan setuju dan $0 \%$ yang menyatakan tidak setuju. Dari pernyataan tersebut dapat disimpulkan bahwa para karyawan setuju dengan pernyataan pekerjaan dapat diselesaikan dengan rasa tanggung jawab, serta tepat pada waktu yang telah ditentukan.

Pada pernyataan kedua yang menyatakan bahwa target kerja yang dibebankan kepada karyawan semua dapat terlampaui dengan baik. Dari pernyataan tersebut sebanyak $12 \%$ dari responden menyatakan sangat setuju, $56 \%$ menyatakan setuju dan $4 \%$ yang menyatakan tidak setuju. Dari pernyataan tersebut dapat disimpulkan bahwa para karyawan setuju dengan target kerja yang dibebankan kepada karyawan semua dapat terlampaui dengan baik.

Pada pernyataan ketiga yang menyatakan bahwa disiplin kerja dan janji pemenang selalu dilaksanakan dengan setulus hati, terus meningkat setiap tahunnya. Dari pernyataan tersebut sebanyak $12 \%$ dari responden menyatakan sangat setuju, $68 \%$ menyatakan setuju dan 6\% yang menyatakan tidak setuju. Dari pernyataan tersebut dapat disimpulkan bahwa para karyawan setuju dengan disiplin kerja dan janji pemenang selalu dilaksanakan dengan setulus hati, terus meningkat setiap tahunnya .

Pada pernyataan keempat yang menyatakan bahwa keluhan dari nasabah setiap evaluasi mengalami penurunan. Sehingga nasabah semakin antusias menabung. Dari pernyataan tersebut sebanyak $32.2 \%$ dari responden menyatakan sangat setuju, $77.53 \%$ menyatakan setuju dan $20 \%$ yang menyatakan tidak setuju. Dari pernyataan tersebut dapat disimpulkan bahwa para karyawan setuju dengan pernyataan kuesoiner keluhan dari nasabah setiap evaluasi mengalami penurunan, sehingga nasabah semakin antusias menabung.

Pada pernyataan kelima yang menyatakan bahwa peningkatan terjadi akibat setiap tahunnya, dilaksanakan program forum peningkatan kinerja (FPK). Dari pernyataan tersebut sebanyak $14 \%$ dari responden menyatakan sangat setuju, $52 \%$ menyatakan setuju dan $4 \%$ yang menyatakan tidak setuju. Dari pernyataan tersebut dapat disimpulkan bahwa para karyawan setuju dengan pernyataan peningkatan terjadi akibat setiap tahunnya, dilaksanakan program forum peningkatan kinerja (FPK) .

\section{Pembahasan}

\section{Analisis Regresi Linear Berganda}

Analisis mengetahui pengaruh antara variabel bebas (Insentif, Kompensasi dan Reward) terhadap Variabel terikat (kinerja karyawan), maka dilakukan dengan menggunakan metode analisis regresi linear berganda. Dengan menggunakan program SPSS maka diperoleh hasil sebagai berikut : 


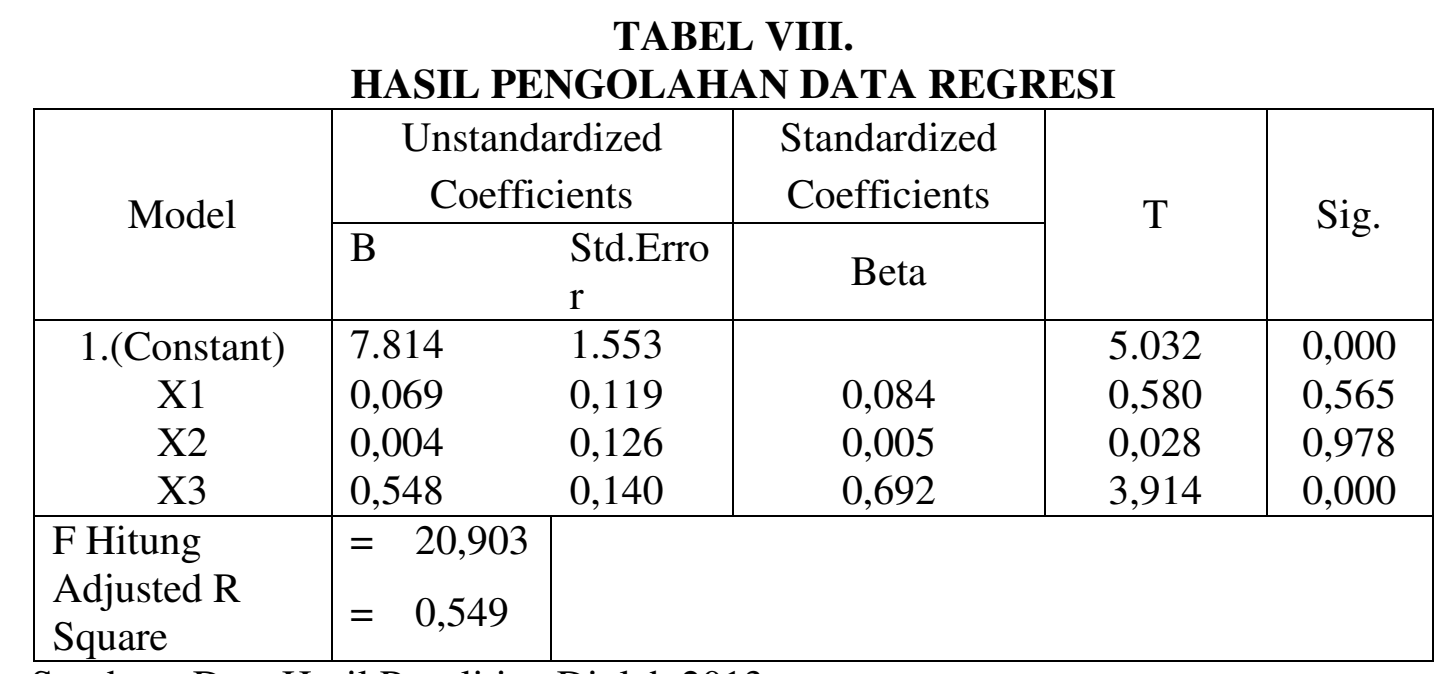

Sumber : Data Hasil Penelitian Diolah,2013

Dari tabel VIII maka persamaan regresinya adalah

$$
\mathrm{Y}=7.814+0.069 \mathrm{X} 1+0.004 \mathrm{X} 2+0.548 \mathrm{X3}
$$

Dari persamaan regresi tersebut dapat diartikan :

1. Nilai konstan pada persamaan regesi diatas 7.814 berarti bahwa nilai dapat artikan nilai Y (Kinerja Karyawan) sebesar $=7.814$ berpengaruh/berhubungan kuat kearah positif dengan asumsi nilai variabel Insentif $(\mathrm{X} 1)=0$, nilai variabel Kompensasi $(\mathrm{X} 2)=0$ dan nilai variabel Reward $(\mathrm{X} 3)=0$.

2. Pengaruh Insentif (X1) terhadap Kinerja Karyawan PT. Bank Rakyat Indonesia Cabang Bengkulu. Hasil penelitian dengan menggunakan persamaan regresi diperoleh bahwa $b 1=0.069$. Ini berarti variabel insentif dinaikan/diturunkan sebesar satu - satuan mempunyai pengaruh/berhubungan kuat kearah positif akan mempengaruhi peningkatan/penurunan kinerja karyawan sebesar satu - satuan juga, dengan asumsi X2 dan X3 tidak berubah.

3. Pengaruh Kompensasi (X2) terhadap Kinerja Karyawan PT. Bank Rakyat Indonesia Bengkulu. Hasil penelitian dengan menggunakan persamaan regresi diperoleh bahwa b2 $=0,004$. Ini berarti berpengaruh kuat kearah positif apabila variabel kompensasi dinaikan/diturunkan sebesar satu - satuan akan mengalami peningkatan/penurunan kinerja karyawan PT. Bank Rakyat Indonesia Cabang Bengkulu sebesar satu-satuan juga, dengan asumsi X1 dan X3 tidak berubah.

4. Pengaruh Reward (X3) terhadap karyawan PT. Bank Rakyat Indonesia Bengkulu. Hasil penelitian dengan menggunakan persamaan regresi diperoleh bahwa b3 = 0.548. Ini berarti variabel reward dinaikan/diturunkan sebesar satu-satuan mempunyai pengaruh/berhubungan kuat kearah positif akan mempengaruhi peningkatan/penurunan kinerja karyawan PT. Bank Rakyat Indonesia Cabang Bengkulu sebesar satu-satuan juga dengan asumsi X1 dan X2 tidak berubah atau $=0$.

5. Determinasi Berganda Adjusted R square

Dari hasil perhitungan dengan menggunakan program SPSS diperoleh Koefisien Determinasi Berganda Adjusted $\mathrm{R}$ square $=0.549$ hal ini berarti bahwa variabel 
insentif (X1), kompensasi (X2), dan reward (X3) memberi sumbangan dalam mempengaruhi kinerja karyawan sebesar $54.9 \%$ sedangkan sisanya $45.1 \%$ merupakan variabel lain yang tidak diteliti dalam penelitian ini. Sedangkan Korelasi Berganda $(\mathrm{R})=0.760$, hal ini berarti terdapat korelasi yang kuat positif (karena besarnya > 0.5), antara variabel insentif (X1), kompensasi (X2) dan reward (X3) secara bersama-sama terhadap kinerja karyawan (Y). Atau memberikan sumbangan pengaruh sebesar $76 \%$

\section{Analisis Pengaruh Secara Bersama - sama}

Untuk menguji pengaruh variabel Insentif, Kompesasi, dan Reward, secara bersama - sama terhadap kinerja karyawan PT. Bank Rakyat Indonesia Cabang Bengkulu, maka digunakan uji F, dari perhitungan didapatkan F hitung sebesar 20,903, sedangkan $\mathrm{F}$ tabel $/ \mathrm{F}(\mathrm{v} 1)(\mathrm{v} 2)$ dengan menggunakan tingkat kepercayaan $95 \%$ atau $\alpha 0.5$ $\%$ dan kebebasan (m-1) (n-m) adalah sebesar 2,81 sehingga $\mathrm{F}$ hitung $>\mathrm{F}$ tabel.

a. jika $\mathrm{F}$ hitung $<\mathrm{F}$ tabel, maka Ho diterima dan Ha ditolak, artinya secara bersama sama variabel $\mathrm{X}$ tidak berpengaruh terhadap variabel $\mathrm{Y}$

b. jika $\mathrm{F}$ hitung $>\mathrm{F}$ tabel, maka Ho ditolak dan Ha diterima, artinya secara bersama sama variabel $\mathrm{X}$ berpengaruh terhadap kinerja karyawan PT. Bank Rakyat Indonesia Cabang Bengkulu variabel $\mathrm{Y}$

\section{Analisis Pengaruh Secara Parsial}

Untuk mengetahui tingkat pengaruh variabel insentif, kompensasi, dan reward secara parsial terhadap kinerja karyawan, maka digunakan uji t atau membandingkan nilai sig hitung dari program analisa SPSS dengan level of sig $\alpha=0.05$. Dari perhitungan statistik, besarnya nilai t dari masing-masing variabel adalah :

t hitung untuk insentif adalah 0,580

thitung untuk kompensasi adalah 0,028

t hitung untuk reward adalah 3,914

Sedangkan untuk melihat dari hasil perbandingan nilai level of sig $\alpha=0,05$ terhadap sig hitung dengan kriteria pengujian :

a. Jika sig hitung $<$ level of sig dengan $\alpha=0.05$, maka Ho ditolak dan $\mathrm{Ha}$ diterima,artinya variabel bebas berpengaruh signifikan terhadap variabel terikat.

b. Jika sig hitung $>$ level of sig dengan $\alpha=0.05$, maka Ho diterima dan Ha ditolak, artinya variabel bebas tidak berpengaruh signifikan terhadap variabel terikat.

c. Dari perhitungan dimuka dapat disimpulkan bahwa secara parsial atau secara sendiri - sendiri, variabel insentif, kompensasi, tidak berpengaruh siginifikan dan variabel reward berpengaruh signifikan terhadap kinerja karyawan PT. Bank Rakyat Indonesia cabang Bengkulu. 


\section{CREATIVE RESEARCH MANAGEMENT JOURNAL-CRMJ Juli}

TABEL IX.

PERBANDINGAN SIG HITUNG DENGAN LEVEL OF SIG $\alpha=0,05$

\begin{tabular}{|l|l|l|l|}
\hline Variabel & Sig-hitung & Level ofSig & Keterangan \\
\hline Insentif & 0,565 & 0,05 & Ho diterima, Ha ditolak \\
Kompensasi & 0,978 & 0,05 & Ho diterima, Ha ditolak \\
Reward & 0,000 & 0,05 & Ho ditolak, Ha diterima \\
\hline
\end{tabular}

Sumber : Data Hasil Penelitian,2013

Dari tabel IX dapat diketahui sig hitung dari variabel insentif, sig hitung dari variabel kompensasi lebih besar dari level of significant dengan kesimpulan Ho diterima dan Ha ditolak serta $\mathrm{t}$ hitung dari variabel reward lebih besar dari t tabel, dengan kesimpulan Ho ditolak dan Ha diterima. Jadi variabel insentif, variabel kompensasi tidak mempunyai pengaruh yang signifikan dan variabel reward secara parsial atau sendiri - sendiri berpengaruh mempunyai pengaruh yang signifikan terhadap kinerja karyawan PT.Bank Rakyat Indonesia cabang Bengkulu.

\section{Pembahasan}

Hasil analisis linear berganda, terdapat hubungan antara variabel Insentif, Kompensasi, dan Reward terhadap Kinerja Karyawan PT. Bank Rakyat Indonesia Cabang Bengkulu, secara bersama - sama terbukti dengan hasil yang mempunyai pengaruh yang signifikan dan secara sendiri - sendiri atau parsial hanya variabel insentif dan variabel kompensasi yang tidak mempunyai pengaruh yang signifikan terhadap kinerja karyawan, sedangkan variabel reward mempunyai pengaruh signifikan terhadap kinerja karyawan.

Hasil penelitian yang berhubungan dengan insentif, menunjukan bahwa sebagian besar karyawan PT. Bank Rakyat Indonesia Cabang Bengkulu setuju bahwa dengan adanya pemberian Insentif setiap tahunnya, jumlah yang diberikan, serta cara mencapai target agar Insentif yang didapatkan sesuai harapan, akan sangat berpengaruh kecil bagi peningkatan kinerja karyawan PT. Bank Rakyat Indonesia Cabang Bengkulu.

Hasil penelitian yang berhubungan dengan kompensasi menunjukan bahwa sebagian besar karyawan PT. Bank Rakyat Indonesia cabang Bengkulu berkenan atau sudi menerima kompensasi (gaji) yang telah diberikan pihak perusahaan sesuai dengan peraturan yang ada, dan telah mendapatkan kesejahteraan yang cukup layak sampai saat ini. untuk kenaikan kompensasi (gaji) yang meningkat setiap tahunnya telah menjadikan kebutuhan hidup setiap karyawan menjadi terpenuhi sehingga hanya sebagian kecil pengaruhnya mendorong karyawan meningkatkan kinerjanya agar perusahaan yang memberikan mereka kesejahteraan tersebut akan terus memperbaiki yang sudah baik lagi demi mencapai yang terbaik.

Hasil penelitian yang berhubungan dengan Reward menunjukan bahwa sebagian besar karyawan PT. Bank Rakyat Indonesia Cabang Bengkulu menyatakan untuk bisa mendapatkan Reward yang setimpal dengan hasil prestasi baik telah tercapai sesuai penilaian masing - masing karyawan, dan masa kerja menjadi salah satu komponen peniliaan serta integritas, propesionalitas kerja dan tanggung jawab menjadi modal 
utama agar perusahaan dapat melihat karyawan yang mana telah berprestasi demi mencapai tujuan utama perusahaan dan mendapatkan kesejahteraan bersama. Perusahaan pun telah mempersiapkan hadiah apa yang sesuai standarisasi prosedur yang ada dengan hasil prestasi gemilang dari para karyawan. Sehingga memotivasi kinerja karyawan menjadi lebih sempurna.

Hasil analisis regersi menunjukkan bahwa variabel Insentif, Kompensasi, dan Reward berpengaruh terhadap Kinerja Karyawan, hal ini dapat di ketahui dari uji $\mathrm{F}$, dimana hasilnya menunjukan bahwa $\mathrm{F}$ hitung lebih besar dari $\mathrm{F}$ tabel, sehingga dapat disimpulkan bahwa ketiga variabel tersebut secara bersama - sama mempengaruhi Kinerja Karyawan PT. Bank Rakyat Indonesia Cabang Bengkulu. Selain itu dapat dilihat dari nilai Adjusted R Square sebesar 0,549, yang berarti bahwa sumbangan variabel insentif, kompensasi dan reward terhadap kinerja karyawan adalah sebesar $54,9 \%$.

\section{Kesimpulan}

1. PT. Bank Rakyat Indonesia (Persero). Tbk Kantor Cabang Bengkulu memiliki karyawan sebanyak 75 (Tujuh Puluh Lima) orang. Terdiri beberapa bagian yang bergerak dalam bidang operasional, Back office, IT , Kredit Lini. Dan bebarapa bagian kecil termasuk Devisi Mikro dan Devisi Kepatuhan. Untuk unit kerja BRI cabang Bengkulu terdiri dari 12 unit BRI, 1 KCP Raflesia, 2 Kantor Kas Becoolen Mall dan UNIB, 1 Mobil Keliling BRI, serta Teras BRI

2. Variabel Insentif, Kompensasi, tidak berpengaruh signifikan menurut pembuktian secara parsial terhadap kinerja karyawan PT. Bank Rakyat Indonesia Cabang Bengkulu. Dan variabel Reward berpengaruh signifikan. Hal ini teruji dan diterima kebenaranya secara statistik.

3. Diantara ketiga variabel tersebut, variabel reward mempunyai pengaruh yang lebih besar yaitu sebesar 54,8\%.

4. Variabel Insentif, variabel Kompensasi dan variabel Reward secara bersama -sama berpengaruh signifikan terhadap Kinerja Karyawan PT. Bank Rakyat Indonesia Kantor Cabang Bengkulu. Hal ini dibuktikan dengan hasil perbandingan antara $\mathrm{F}$ hitung dengan $\mathrm{F}$ tabel.

\section{Saran}

1. Variabel Reward perlu mendapat perhatian yang lebih khusus dari perusahaan karena variabel ini mempunyai pengaruh yang paling dominan terhadap kinerja karyawan PT. Bank Rakyat Indonesia Kantor Cabang Bengkulu. Oleh itu perlu diperhatikan yang mana karyawan telah menunjukan prestasi yang memuaskan dan menunjukan totalitas kinerjanya agar diberikan imbalan yang sesuai bahkan mendorong Karyawan lainnya lebih baik lagi.

2. Perlu dikaji dan dilakukan penelitian baru terhadap variabel yang belum terdapat di skripsi ini, terutama variabel - variabel yang dapat mempengaruhi Kinerja Karyawan diantaranya motivasi, pengalaman, lingkungan kerja. 


\section{DAFTAR PUSTAKA}

Dwiloka, Bambang, Riana, Rati. 2005. Teknik Menulis Karya Ilmiah. Jakarta: PT. Rineka Cipta.

Flippo, Edwin, B. 1989. Manajemen Personalia Edisi Keenam Jilid 2 : Bagian Kompensasi. Jakarta: Erlangga.

Hani, H. T. 1999. Manajemen Edisi 2 : Penyusunan Personalia Organisasi. Yogyakarta: BPPE.

Hasibuan, Malayu, S . P. 2005. Manajemen : Dasar, Pengertian, Dan Masalah. Jakarta: PT. Bumi Aksara.

Julitriarsa, Djati, Suprihanto, Jhon. 2001. Manajemen Umum Sebuah Pengantar Edisi Pertama: Pendahuluan. Yogyakarta: BPFE Yogyakarta.

Lovita, Selly. 2012. Pengaruh Gaya Kepemimpinan Dan Insentif Terhadap Kinerja Karyawan PT. Sumber Cipta Multiniaga : Landasan Teori. Bengkulu: Fakultas Ekonomi UNIHAZ.

Nitisemito, Alex, S. 1991. Manajemen Personalia : Kompensasi.Jakarta: Ghalia Indonesia.

Notoatmodjo, Soekidjo. 2003. Pengembangan Sumber daya Manusia : Sistem Pemberian Kompensasi. Jakarta: PT. Rineka Cipta.

Safitri, A. M. 2010. Pengaruh Lingkungan Kerja, Pendidikan, dan Pengalaman Terhadap Prestasi Kerja PT. Sari Husada Cabang Bengkulu : Metode Penelitian. Bengkulu: Fakultas Ekonomi UNIHAZ.

Suheti, Leli. 2002. Pengaruh Pemberian Kompensasi Terhadap Produktivitas Kerja Karyawan Usaha Kerupuk Sukasari di Manna Bengkulu Selatan : Tinjauan Pustaka. Bengkulu: Fakultas Ekonomi UNIHAZ.

Siagian, Sondang, P. 2007. Manajemen Sumber Daya Manusia : Sistem Imbalan. Jakarta: PT. Bumi Aksara.

Sukotio, Ibnu, dkk.1999. Pengantar Bisnis Modern (Pengantar Ekonomi Perusahaan Modern) : Metode Pengupahan. Yogyakarta: Liberty

Usman, Rianse,M.S, Abdi. 2008. Metodologi Penelitian Sosial dan Ekonomi Teori Dan Aplikasi : Merumuskan Metode Penelitian. Bandung: Alfbeta 